\title{
Sistem Pakar Perencanaan Penjadwalan Bangunan Rumah Minimalis Berdasarkan Tipe dengan Metode Algoritma Genetika
}

\author{
Budi Harijanto $^{1}$, Rizky Ardiansyah ${ }^{2}$, Muhammad Aspandji Aspudji $^{3}$ \\ 1,2,3 Teknik Informatika, Teknologi Informasi, Politeknik Negeri Malang \\ 1'budi.harijanto@ polinema.ac.id, ${ }^{2}$ risky.computerscience@gmail.com, ${ }^{3}$ muhammadaspandji498@gmail.com
}

\begin{abstract}
Abstrak
Seiring dengan cepatnya pertumbuhan penduduk, sejalan pula dengan meningkatnya tingkat pertumbuhan pembangunan salah satunya pembangunan rumah. Pembangunan rumah menjadi salah satu faktor yang penting mengingat dengan fungsinya tidak hanya sebagai untuk tempat tinggal namun juga sudah menjadi kebutuhan primer bagi manusia. Sampai saat ini, tidak jarang saat seseorang ingin membangun sebuah rumah, hanya memperkirakan tipe yang diinginkan dan persiapan dana tanpa mengetahui persis kebutuhan apa saja yang diperlukan dengan jumlah persiapan dana yang ada. Juga dalam pelaksanaan pembangunan rumah sering kali terjadi keterlambatan dikarenakan penjadwalan yang kurang optimal. Untuk mengakomodasi permasalahan tersebut, maka diperlukan sebuah aplikasi penjadwalan durasi pembangunan berbasis web yang sistematis dan terintegrasi dengan melibatkan beberapa komponen yang penting yang ada sehingga dapat meminimalisir dampak keterlambatan penjadwalan. Juga dapat mengetahui dengan rinci, kebutuhan yang diperlukan sesuai dengan persiapan dana yang ada. Pembuatan aplikasi dilakukan dengan menerapkan metode Algoritma Genetika untuk melakukan optimasi biaya dan penjadwalan kegiatan. Dalam penerapan metode Algoritma Genetika, dilakukan percobaan nilai kombinasi parameter pada rumah tipe 36 dan didapatkan nilai kombinasi terbaik dengan nilai Kromosom: 100, Jumlah generasi: 80, Probabilitas Crossover: 0,7 dan Probabilitas Mutasi 0,05 didapatkan nilai pengoptimalan durasi 84 hari, biaya atau harga Rp. 107.069.329 dan nilai fitness 0,0937 dengan tingkat akurasi sebesar 91,6\%. Dengan hasil tersebut maka aplikasi ini dinilai optimal untuk melakukan penjadwalan dan optimasi biaya sesuai dengan kebutuhan.
\end{abstract}

Kata kunci : algroritma genetika, optimasi Biaya, penjadwalan pembangunan

\section{Pendahuluan}

Seiring dengan bertambahnya penduduk sejalan pula dengan petumbuhan bangunan sebagai tempat bernaung. Bangunan yang berfungsi sebagai tempat tempat tinggal biasanya disebut dengan rumah. Kebutuhan manusia akan rumah tinggal tidak bisa dipandang sebelah mata saja, karena ini merupakan kebutuhan primer setiap manusia. (Simbolon \& Nasution, 2017)

Rumah minimalis pun hadir dengan karakter lebih jelas (bentuk dan ruang geometris, sederhana), lebih baik (kokoh), dan lebih kuat dengan ruangruang yang kosong (sedikit ornamen dan perabotan). Prinsipnya semakin sederhana, maka kualitas desain, ruang yang ada, dan penyelesaian bidang struktur harus semakin lebih baik. John Pawson yang dianggap sebagai guru "minimalisme" menghadirkan desain rumah yang minim garis, suasana yang hening dan indah. ( Murtomo, 2008)

Sebelum membangun rumah tinggal, sebaiknya dilakukan perencanaan dan memberikan gambaran tipe rumah minimalis yang hendak dipilih, adapun beberapa tipe yang dapat menjadi pertimbangan pemilik yaitu tipe 36 dan 45 . Dalam pelaksanaan pembangunan rumah sering kali mengalami keterlambatan dikarenakan penjadwalan yang kurang optimal. Untuk meminumkan keterlambatan, penjadwalan harus dibuat lebih efektif dan realistis, yaitu penjadwalan sistematis yang terintegrasi dengan berbagai komponen proyek, seperti waktu, sumber daya, dan biaya proyek. Biaya proyek bersifat penting dan sensitif dalam suatu perencanaan proyek (MUZDALIFAH, KURNIAWATI, ULUL, \& PAMITRA, 2019). Penjadwalan yang kurang tepat dapat menimbulkan peningkatan biaya dan akan merugikan calon pemilik rumah.

Penelitian terhadap masalah optimasi penjadwalan menggunakan algoritma genetika telah banyak dipelajari dan dikembangkan oleh beberapa penelitian diantaranya: (Krisnandi \& Agung, 2017) yang membuat penelitian tentang "Implementasi Algoritma Genetika untuk Memprediksi Waktu dan Biaya Pengerjaan Proyek Konstruksi" dengan Algoritma Genetika yang digunakan untuk membangun aplikasi yang dapat memprediksi waktu 
dan biaya pengerjaan proyek konstruksi mendapatkan hasil penelitian adalah $98.72 \%$.

Penelitian ini akan menggunakan algoritma genetika untuk melakukan optimasi biaya dan waktu terhadap kegiatan dalam pengerjaan pembangunan rumah minimalis. Algoritma genetika adalah algoritma pencarian (search algorithm) yang menggunakan prinsip seleksi alam dalam ilmu genetika untuk mengembangkan solusi terhadap permasalahan. Konsep dasar algoritma genetika adalah mengelola suatu populasi individu yang merepresentasikan kandidat solusi sebuah optimasi perencanaan penjadwalan pembangunan rumah.

Sistem ini dibuat bertujuan mengetahui durasi optimal pengerjaan pembangunan rumah dan biaya yang timbul akibat optimalisasi serta menganalisa karateristik metode algoritma genetika. Pemilihan penggunaan metode Algoritma Genetika dalam hal ini berdasarkan penelitian terdahulu yang menunjukkan presentase keakuratan metode ini cukup tinggi.

Pencapaian dari penelitian ini akan menghasilkan sistem informasi yang dapat memberikan informasi spesifikasi rumah serta output penjadwalan yang optimal dengan mempertimbangkan waktu dan biaya. Penjadwalan pembangunan yang sudah dioptimasi dengan algoritma genetika diharapkan dapat menjadi solusi dan informasi bagi calon pemilik rumah.

\section{Tinjauan Pustaka}

Pada penelitian yang dilakukan oleh Riza Arifudin yang berjudul "Optimasi Penjadwalan Proyek dengan Penyeimbangan Biaya Menggunakan Kombinasi CPM dan Algoritma Genetika". Melakukan penelitian dengan mengkombinasikan CPM dengan algoritma genetika untuk melakukan penjadwalan sebuah proyek. Alokasi kegiatan ditentukan berdasarkan waktu mulai paling awal dan waktu mulai terakhir dengan memperhitungkan biaya dalam sumber daya setiap periode proyek. Penjadwalan proyek dan kriteria optimal digunakan untuk meminimalkan biaya penyimpangan dari ratarata total biaya proyek. Hasil yang diperoleh dalam penelitian ini dengan kombinasi CPM dan algoritma genetika dapat menghasilkan jadwal proyek lebih cepat dan biaya proyek per hari juga lebih hemat. (Arifudin , 2012)

Penelitian selanjutnya dilakukan oleh Kevin Krisnandi, Halim Agung berjudul "Implementasi Algoritma Genetika untuk Memprediksi Waktu dan Biaya Pengerjaan Proyek Konstruksi”. Algoritma yang digunakan untuk membangun aplikasi yang dapat memprediksi waktu dan biaya pengerjaan proyek konstruksi adalah algoritma genetika. Hasil yang diperoleh dalam penelitian ini adalah $98.72 \%$ keakuratannya dalam memprediksi waktu dan biaya pengerjaan proyek konstruksi yang dimana aplikasi ini dapat memberikan output berupa hasil prediksi waktu dan biaya pengerjaan proyek konstruksi berdasarkan luas tanah yang di input dan pemilihan kromosom. Kromosom yang dimaksud adalah salah satu pekerjaan dari masing - masing proyek, yang memiliki luas tanah dengan selisih 5 angka dari luas tanah yang di input. Hasil ini didapat dengan total pengujian sebanyak 25 kali pengujian. (Krisnandi \& Agung, 2017)

\subsection{Sistem Pakar}

Sistem pakar adalah suatu program komputer yang mengandung pengetahuan dari satu atau lebih pakar manusia mengenai suatu bidang spesifik. Jenis program ini pertama kali dikembangkan oleh periset kecerdasan buatan pada dasawarsa 1960-an dan 1970-an dan diterapkan secara komersial selama 1980-an. Bentuk umum sistem pakar adalah suatu program yang dibuat berdasarkan suatu set aturan yang menganalisis informasi (biasanya diberikan oleh pengguna suatu sistem) mengenai suatu kelas masalah spesifik serta analisis matematis dari masalah tersebut.Tergantung dari desainnya, sistem pakar juga mampu merekomendasikan suatu rangkaian tindakan pengguna untuk dapat menerapkan koreksi. Sistem ini memanfaatkan kapabilitas penalaran untuk mencapai suatu simpulan ( SETIAWAN, 2014)

\subsection{Algoritma Genetika}

Algoritma genetika ditemukan oleh John $\mathrm{H}$. Holland dari university of Michigan yang memulai penelitiannya pada tahun 1960. Dalam penelitian Holland penerapan algoritma genetika dikaitkan dengan metode adaptif untuk memecahkan masalah dan optimasi. (Arifudin , 2012)

Algoritma genetika banyak digunakan untuk menyelesaikan berbagai masalah optimasi. Algoritma genetika bukanlah algoritma yang proses penyelesaiannya berdasarkan perhitungan matematika melainkan proses penyelesaiannya memanfaatkan analogi mekanisme seleksi alam dan mekanisme kawin silang, mutasi, inversi, dan lainlain yang terdapat pada proses genetika alam (Maharani, 2015)

\section{Analisa Sistem}

\subsection{Gambaran Umum Sistem}

Implementasi untuk sistem pakar perencanaan pembangunan rumah minimalis ini berupa sebuah optimasi penjadwalan yang menerapkan model dari algoritma genetika. Untuk menyelesaikan permasalahan optimasi penjadwalan kegitan pembangunan rumah minimalis ini diasumsikan bahwa setiap kegiatan dalam proses pembangunan rumah mempunyai durasi dan biaya pelaksanaan kegiatan yang tetap. Data masukan untuk melakukan penjadwalan adalah data kegiatan dan biaya tiap 
item kegiatan yang selanjutnya akan diproses dengan menggunakan perhitungan algoritma genetika.

\subsection{Analisa Algoritma Genetika dalam sistem}

1. Inisiasi Populasi Awal

Pada penelitian ini, sebuah kromosom menyatakan sebuah soslusi perencanaan penjadwalan pembangunan rumah minimalis. Kromosom yang akan direpresentasikan terdiri dari kumpulan gen yang berisi informasi durasi kegiatan pekerjaan. Panjang kromosom adalah $n$, dengan $n$ adalah banyaknya kegiatan atau pekerjaan. Pada sistem ini satu gen mewakili durasi satu kegiatan atau pekerjaan. Nilai setiap gen adalah bilangan bulat yang diperoleh secara acak (random) dengan interval yang telah ditentukan (durasi pekerjaan).

\section{Menentukan fungsi fitnes}

Pada sistem ini fungsi objektifnya adalah mengoptimalkan durasi dan biaya yang diakibatkan oleh penjadwalan (B). Fungsi objektif dalam sistem ini dituliskan sebagai berikut:

$$
\begin{aligned}
& B=\sum_{i=1}^{n} b[i] \\
& \text { Dimana: } \\
& \mathrm{B} \quad=\text { Total biaya yang } \\
& \text { penjadwalan } \\
& \mathrm{n} \quad=\text { Jumlah item pekerjaan } \\
& \mathrm{i} \quad=\text { nomor kegitan } \\
& \mathrm{b} \quad=\text { Biaya item pekerjaan }
\end{aligned}
$$$$
\mathrm{B}=\text { Total biaya yang diakibatkan oleh }
$$

Pada optimasi durasi dan biaya tiap item kegiatan, akan mengalami percepatan waktu yang mengakibatkan biaya tiap item pekerjaan berubah berdasarkan durasi penyelesaian proyek, dirumuskan dengan persamaan:

$$
b=\frac{\text { Waktu normal X Biaya normal }}{\text { Waktu Crashing }}
$$

Fungsi objektif pada sistem ini adalah meminimumkan fungsi B sehingga fungsi fitnessnya dapat dirumuskan dengan persamaan:

$$
f=\frac{1}{(B / 10000000)}
$$

Dimana B adalah total biaya yang diakibatkan oleh penjadwalan.

\section{Seleksi}

Pada penelitian ini seleksi kromosom dilakkuan menggunakan seleksi roda roulette (Roulette Wheel Selection). Langkah-langkah proses seleksi kromosom adalah sebagi berikut:

a. Jumlahkan hasil total fitness yang didapatkan dari tiap kromosom.

$$
\text { Total fitnes } \sum_{i=1}^{n} f[i]
$$

b. Kemudian menghitung nilai probalitas kromosom didapat dari membagi nilai fitness tiap kromosom dengan total fitness

$$
P_{k}=\frac{f[i]}{\text { total_fitnes }_{\text {fitn }}}
$$

c. Selanjutnya hitung komulatif probalitas kromosom

$$
C[i]=\sum_{j=1}^{n} P[j]
$$

d. Membangkitkan bilangan acak random dengan interval $[0,1]$

$$
R[k]=\text { random }
$$

Dimana $\mathrm{k}=1$ sampai jumalh kromosom

e. Memilih kromosom yang akan dipertahankan dengan ketentuan:

f. Jika $\mathrm{R}[\mathrm{k}]<\mathrm{C}[1]$ maka pilih chromosome 1 sebagai induk, selain itu pilih chromosome ke-k sebagai induk dengan syarat $\mathrm{C}[\mathrm{k}-1]<\mathrm{R}$ $<\mathrm{C}[\mathrm{k}]$. Diputar sebanyak jumlah populasi dan pada tiap putaran, pilih satu chromosome untuk populasi baru.

\section{Pindah Silang (Crossover)}

Crossover bertujuan untuk menambah keanekaragaman string dalam satu populasi dengan penyilangan antar string yang diperoleh dari reproduksi sebelumnya. Hasil crossover 2 kromosom induk akan menghasilkan 2 offspring, sehingga jumlah populasi akan bertambah 2 kali jumlah populasi awal [4]. Pada penelitian ini metode Crossover yang digunakan adalah metode one-point crossover atau crossover satu titik, berikut Langkahlangkah proses Crossover:

a. Tentukan Probalitas Crossover (Pc).

b. Bangkitkan bilangan acak (Rk) dengan interval $[0,1]$ untuk setiap kromosom pada proses seleksi.

c. Memilih kromosom sebagai induk (parent) dengan ketentuan jika $\mathrm{R}[\mathrm{k}]<\rho \mathrm{c}$.

d. Menentukan posisi Crossover Dengan cara membangkitkan bilangan acak, dengan batasan 1 sampai $\mathrm{n}-1$, dimana $\mathrm{n}$ adalah panjang kromosom sebanyak Crossover yang terjadi

e. Proses Crossover

Tukarkan bagaian kromosom yang menjadi induk 1 dengan induk 2 dari titik Crossover yang sudah ditentukan. Berikut gambaran ilustrasi yang dapat dilihat pada gambar 1 .

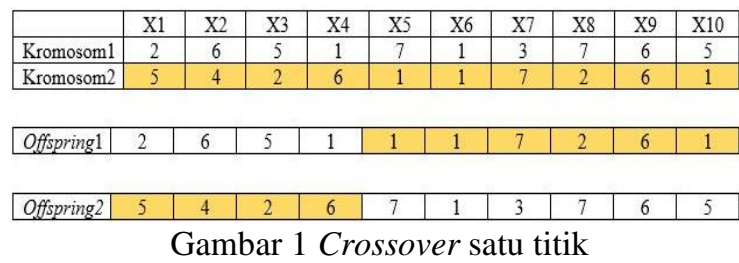

5. Mutasi

Proses mutasi adalah suatu proses kemungkinan memodifikasi informasi gen-gen pada suatu kromosom. Mutasi ini berperan untuk menggantikan suatu nilai gen yang hilang dari proses seleksi yang memungkinkan munculnya kembali nilai gen yang tidak muncul pada saat inisialisasi populasi awal. Pada mutasi terdapat satu parameter yang sangat penting, yaitu peluang mutasi (Pm). Pm didefinisikan sebagai persentasi dari jumlah total gen dalam populasi yang akan 
mengalami mutasi. Berikut langkah-langkah proses mutasi:

a. Menentukan probalitas mutasi (Pm)

b. Menghitung total gen

c. Menentukan jumlah mutasi

Jumlah mutasi $=P m X$ total gen

d. Membangkitkan bilangan acak (a) dengan interval $[0,1]$ sebanyak total gen.

e. Memilih posisi gen yang kan dimutasi dengan ketentuan Jika a < Pm maka gen ke-x akan mengalami mutasi.

f. Kemudian ganti informasi gen tersebut. Nilai gen yang terkena proses mutasi nilainya akan diganti secara random dengan nilai gen yang sudah ditetapkan (durasi pekerjaan).

\section{Update Populasi}

Setelah melalui proses seleksi, Crossover, dan mutasi maka populasi baru terbentuk. Populasi baru ini akan menggantikan populasi lama, pada algoritma genetika, suatu populasi dirancang untuk memiliki jumlah individu yang selalu tetap pada setiap generasi. Pada proses update populasi penelitian ini menggunakan metode steady state berbasis nilai fitness.

\section{Implementasi dan Pengujian}

\subsection{Implementasi Interface}

Implementasi interface merupakan rancangan tata letak tampilan dari aplikasi yang dibangun. Design interface menjadi perantara yang menjembatani interaksi antara pengguna dengan aplikasi yang dibangun, yang berupa komponen tampilan dan tata letak dari komponen tampilan tersebut. Pada desain interface sistem pakar menggunakan metode Algoritma Genetika :

\section{Halaman Generate Jadwal}

Pada halaman Generate penjadwalan dapat dilihat pda gambar 2, user dapat melakukan optimasi penjadwalan dengan memasukkan parameter yang diperlukan untuk proses algoritma genetika yaitu Jumlah kromosom yang akan dibangkitkan, maksimal generasi, Probalitas crossover $(\mathrm{Pc})$ dan probalitas mutasi $(\mathrm{Pm})$.

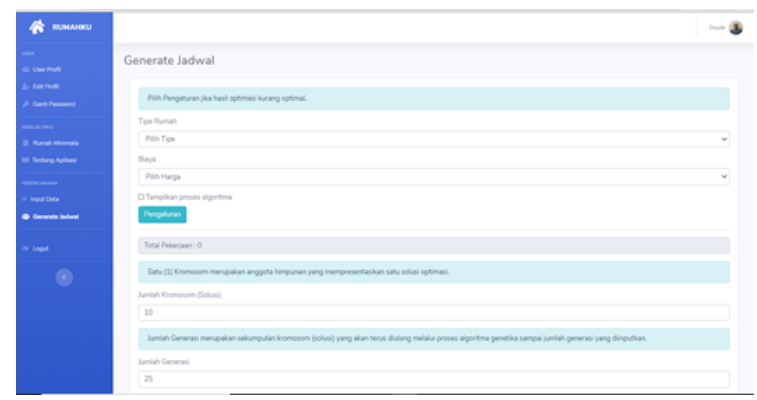

Gambar 2 Halaman Generate Jadwal
Pada halaman hasil optimasi penjadwalan dapat dilihat pada gambar 3 , berisi hasil optimasi penjadwalan yang telah melalui proses algoritma genetika dan akan ditampilkan dalam bentuk jadwal timeline pekerjaan.

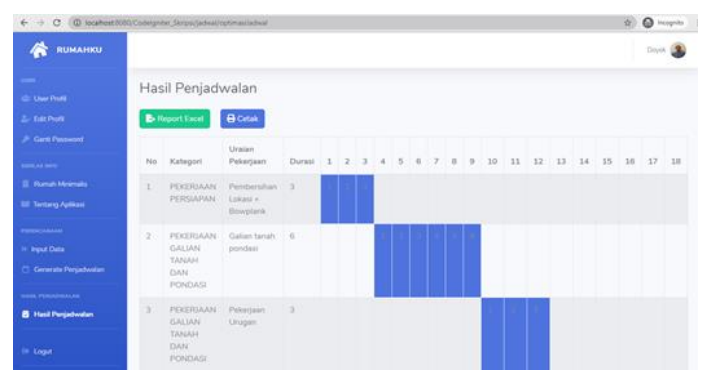

Gambar 3 Hasil Penjadwalan

\subsection{Pengujian Metode}

Untuk menguji hasil penerapan algoritma genetika melalui pengujian yang dilakukan dengan menggunakan parameter algoritma genetika yang bervariasi seperti pada ukuran populasi, kombinasi probabilitas crossover, probabilitas mutasi, dan jumlah generasi.

\section{Pengujian Ukuran Jumlah Kromosom (Populasi)}

Pada pengujian pertama dilakukan pengujian terhadap parameter ukuran populasi yang dapat dilihat pada gambar 4. Pengujian ukuran populasi dilakukan untuk mengetahui pengaruh ukuran populasi terhadap nilai fitness yang dihasilkan dengan kombinasi PC 0,7 dan PM 0,25.

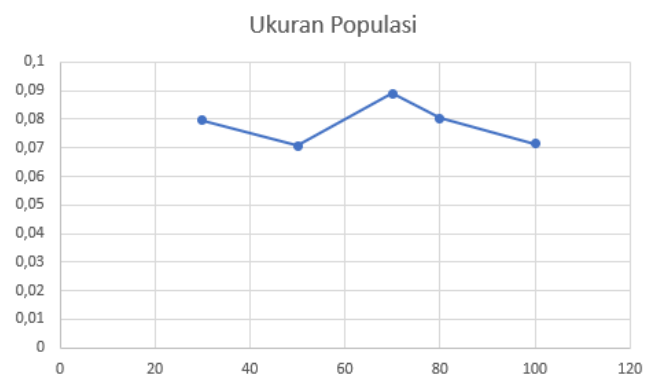

Gambar 4 Grafik Pengujian Jumlah Kromosom

\section{Pengujian Ukuran Generasi}

Pengujian kedua adalah pengujian terhadap parameter jumlah generasi yang digunakan dapat dilihat pada gambar 5. Pengujian jumlah generasi dilakukan untuk mengetahui pengaruh jumlah generasi terhadap nilai fitnees yang dihasilkan dengan kombinasi PC 0,7 dan PM 0,25.

2. Halaman Hasil Optimasi Penjadwalan 


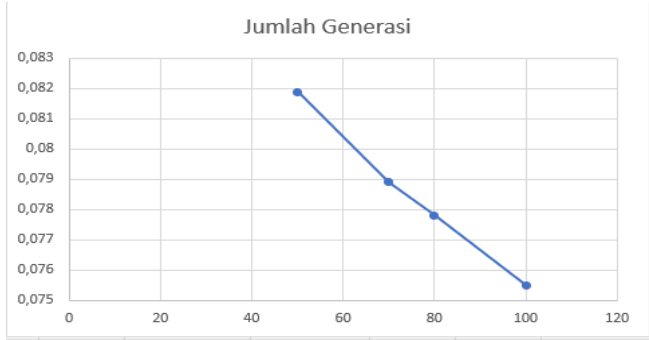

Gambar 5 Grafik Pengujian Jumlah Generasi

3. Pengujian Kombinasi Probabilitas Crossover dan Probabilitas Mutasi

Pengujian ketiga dilakukan dengan pengujian terhadap parameter kombinasi probabilitas crossover (pc) dan probabilitas mutasi (pm) yang digunakan dalam proses algoritma genetika dapat dilihat pada gambar 6. Pengujian kombinasi cr dan mr dilakukan untuk mengetahui pengaruh kombinasi pc dan pm terhadap nilai fitness yang dihasilkan.

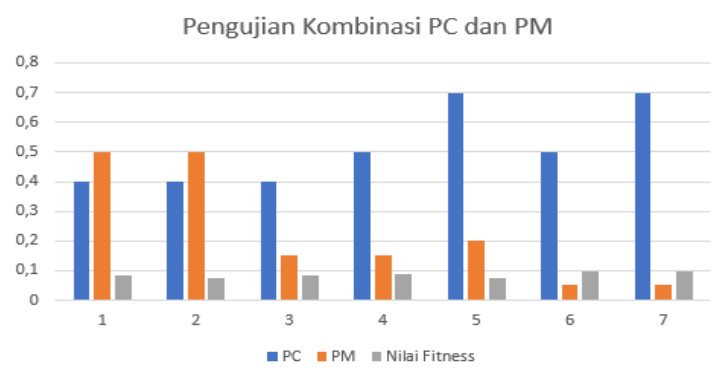

Gambar 6 Grafik Pengujian Pc dan Pm

\section{Hasil dan Pembahasan}

\subsection{Hasil Penelitian}

Hasil dari penelitian ini diperoleh untuk mengukur kualitas solusi terbaik pada permasalahan optimasi penjadwalan perencanaan pembangunan rumah minimalis yaitu dengan melihat nilai fitness tertinggi. Fitness tertinggi adalah individu yang memiliki solusi yang paling optimum berdasarkan sistem. Pengujian parameter algoritma genetika memiliki pengaruh terhadap nilai fitness yang dihasilkan. Pengujian dilakukan dengan menggunakan parameter algoritma genetika yang bervariasi seperti pada ukuran populasi, kombinasi probabilitas crossover dan probabilitas mutasi, dan jumlah generasi. Pengujian pada parameter ukuran populasi yang terbaik terdapat pada ukuran jumlah kromosom (populasi) 100, Jumlah generasi 80, Probabilitas Crossover: 0,7 dan Probabilitas Mutasi 0,05 dengan hasil pengoptimalan penjadwalan pembangunan rumah tipe 36 dengan durasi 84 hari dan total biaya Rp. 107.069.329 dengan nilai fitness 0,0937 dari perkiraan durasi awal 90 hari dengan biaya Rp. 80.0000 .000 yang telah divalidasi oleh pakar dengan tingkat akurasi sebesar 91,6\%.

\subsection{Pembahasan}

Berdasarkan hasil percobaan yang sudah dilakukan dapat dilihat pada gambar grafik 4, jumlah kromosom yang dibangkitkan (populasi) akan berpengaruh terhadap nilai fitness yang diperoleh dari proses perhitungan algoritma genetika. Pada pengujian yang telah dilakukan jumlah kromosom pada ukuran terbesar mengalami penurunan nilai fitness.

Pada hasil percobaan jumlah generasi yang sudah dilakukan dapat dilihat pada gambar grafik 5, diperoleh bahwa jumlah generasi berpengaruh terhadap nilai fitness yang dihasilkan. Pada pengujian yang sudah dilakukan jumlah generasi yang besar nilai fitnessnya cenderung menurun hal ini dapat disimpulkan bahwa jumlah generasi yang tinggi atau besar belum tentu menjadi solusi yang terbaik.

Pada hasil yang diperoleh dari percobaan kombinasi probabilitas crossover dan probabilitas mutasi yang sudah dilakukan dapat dlihat pada gambar grafik 6, nilai fitness mengalami kenaikkan seiring dengan bertambahnya nilai probabilitas crossover dan berkurangnya nilai probabilitas mutasi. Tingkat probabilitas crossover yang kecil dan probabilitas mutasi yang besar akan akan menurunkan kemampuan algoritma genetika untuk melakukan eksploitasi.

Selanjutnya berdasarkan hasil percobaan nilai kombinasi parameter didapatkan nilai kombinasi terbaik dengan nilai Kromosom: 100, Jumlah generasi: 80, Probabilitas Crossover: 0,7 dan Probabilitas Mutasi 0,05 pada tipe rumah 36 didapatkan nilai pengoptimalan durasi 84 hari, total harga Rp. 107.069.329 dan nilai fitness 0,0937 kemudian dilakukan tingkat akurasi dengan menganalisa penjadwalan pekerjaan pembangunan rumah minimalis yang dihasilkan oleh sistem didapatkan 2 pekerjaan dari total 24 pekerjaan yang salah sehingga dapat disimpulkan tingkat akurasi metode algoritma genetika sebesar 91,6\%.

\section{Kesimpulan dan Saran}

\subsection{Kesimpulan}

Sistem mampu memberikan informasi berupa gambaran kebutuhan pembangunan rumah sesuai dengan persiapan dana yang dimiliki dan tipe yang dinginkan

Sistem mampu menerapkan metode algoritma genetika pada tipe rumah 36 dengan memperoleh nilai optimal dengan durasi 84 hari, biaya $\mathrm{Rp}$. 107.069.329 dengan rata-rata nilai fitness 0,0937 dari perkiraan durasi awal 90 hari dan biaya Rp. 80.0000.000 dengan tingkat akurasi sebesar 91,6\%.

Karakteristik algoritma genetika dapat dilihat dari pengujian parameter algoritma genetika dimana jika jumlah kromosom yang dibangkitkan dengan ukuran besar maka akan cenderung mengalami penurunan nilai fitness, lalu pada jumlah generasi hampir sama seperti jumlah kromosom jika jumlah generasi besar maka nilai fitness juga akan mengalami penurunan nilai fitness dan pengkombinasian parameter probabilitas crossover 
dan probabilitas mutasi yang sudah diuji dapat disimpulkan bahwa nilai fitness mengalami kenaikkan seiring dengan bertambahnya nilai probabilitas crossover dan berkurangnya nilai probabilitas mutasi dan tingkat probabilitas crossover yang kecil dan probabilitas mutasi yang besar akan akan menurunkan kemampuan algoritma genetika untuk melakukan eksploitasi.

\subsection{Saran}

Sistem ini dapat dikembangkan dengan menggabungkan 2 metode dan dapat dicoba dengan menggunakan metode metaheuristik lainya seperti metode ant colony dan cuckoo search.

\section{Daftar Pustaka:}

Aji, A. H., Furqon, M. T., \& Widodo, A. W. (2018). Sistem Pakar Diagnosa Penyakit Ibu Hamil Menggunakan Metode Certainty Factor (CF). Jurnal Pengembangan Teknologi Informasi dan Ilmu Komputer Vol. 2, No. 5.

Anggraeni, W., Utamima, A., \& Siregar, K. J. (2015). Optimasi Penjadwalan Proyek Menggunakan Algoritma Genetika. Jurnal Sistem Informasi, Volume 5, Nomor 3, 302307

Arifudin, R. (2012). Optimasi Penjadwalan Proyek dengan Penyeimbangan Biaya Menggunakan Kombinasi CPM dan Algoritma Genetika. Jurnal Masyarakat Informatika, Volume 2, Nomor 4, 14.

Ashari,I. A. (2016) "Perbandingan Performansi Algoritma Genetika dan Algoritma Ant Conlony Optimazition Dalam Optimasi Penjadwalan Mata Kuliah". Semarang: Universitas Negeri Semarang.

Chasanah, M. (2018). "Sistem Pakar Mengukur Tingkat Stres Mahasiswa di Politeknik Negeri Malang Dengan Metode Neuro Fuzzy". Malang: Politeknik Negeri Malang.

Damayanti, C. P., Putri, R. R., \& Fauzi, M. A. (2017). Implementasi Algoritma Genetika Untuk Penjadwalan Customer Service (Studi Kasus: Biro Perjalanan Kangoroo). Jurnal Pengembangan Teknologi Informasi dan Ilmu Komputer Vol. 1, No. 6.

Ilmi, R. R., Mahmudy, W. F., \& Ratnawati, D. E. (2015). Optimasi Penjadwalan Perawat Menggunakan Algoritma Genetika. Jurnal Mahasiswa PTIIK Universitas Brawijaya, vol. 5, no. 13 .

Krisnandi, K., \& Agung, H. (2017). Implementasi Algoritma Genetika untuk Memprediksi Waktu dan Biaya Pengerjaan Proyek Konstruksi. JURNAL ILMIAH FIFO Volume IX/No.2, 8.

Maharani, F. (2013). "Sistem Penjadwalan Proyek Menggunakan Algoritma Genetika".
PEKANBARU: UNIVERSITAS ISLAM NEGERI SULTAN SYRARIF KASIM.

Murtomo, B. A. (2008). Studi Sistem Pembayangan Pada Rumah Minimalis Studi kasus pada Perumahan Mega Residence, Semarang. Jurnal Ilmiah Perancangan Kota dan Permukiman Volume 7 No. 1, 8.

MUZDALIFAH, L., KURNIAWATI, E. F., ULUL, E. D., \& PAMITRA, K. G. (2019). Penjadwalan Proyek Perumahan Dengan Optimasi Waktu Dan Biaya Harian. Jurnal Riset dan Aplikasi Matematika Vol. 03 No. 02.

Rosiani, U. D., Permatasari, T. H., \& Yunhasnawa, Y. (2018). Sistem Pakar Emosi Wanita Jawa Menggunakan Metode Certainty Factor. Jurnal Informatika Polinema Volume 4, Edisi 3., 6 .

SETIAWAN, A. B. (2014). Kecerdasan Buatan Sistem Pakar Mendiagnosa Penyakit Ginjal. Makalah Sistem Pakar.

Simbolon, H., \& Nasution, I. N. (2017). Desain Rumah Tinggal Yang Ramah Lingkungan Untuk Iklim Tropis. JURNAL EDUCATION BUUILDING Volume 3, Nomor 1, 14.

Sugeha, I. H., Inkiriwang, R. L., \& Pratasis, P. A. (2019). Optimasi Penjadwalan Menggunakan Metode Algoritma Genetika Pada Proyek Rehabilitasi Puskesmas Minanga. Jurnal Sipil Statik Vol.7 No.12.

Yulianto, A. (2013). Optimasi Penjadwalan Proyek Menggunakan CPM Dengan Algoritma Genetika Pada Studi Kasus Proyek Pembangunan Labotarium Ekonomi Ubhara Surabaya. Jurnal Teknik Sipil Untag Surabaya Vol. 06, No. 02, 35 - 42. 